proportions. The Central Library (I'IL3) of the Ministry of Aviation has accordingly performed a most valuable service to those intcrested in this rapidly growing field of research by issuing a bibliography with brief abstracts covering tho period Decomber 1958-May 1962 (Bibliographical Series, No. 4: Lasers. Compiled by K. J. Spencer. Pp. $i+39$. London: Ministry of Aviation, 1962). Tho abstracts aro short, but give an indication of the contonts of most papers. Some indication of the rate of growth of the subject may be gathered from the number of reforences quoted: 1958, 2; 1959, 10; 1960,$19 ; 1961,168 ; 1962$ (January-May), 129. About eighty more references from symposia proceedings are also given. The references deal not only with the physics of laser action, but also with their achieved, proposed and droamed of applications.

\section{Foundations of a Flora}

MANY of those who have rightly admired Sir Joseph Dalton Hooker's great achievement in producing his Flora Tasmaniae (London, 1860), with its important introductory essay on plant geography and its bearing on evolutionary fact and theory, may porhaps not have appreciated how much he was helped by a long series of roports and collections of specimens mado to his father, Sir William Jackson Hooker, and to himself, by local 'Tasmanian naturalists and collectors. In fact, as it now appears, he received an astonishing amount of information from local sources. T. F. Burns and J. R. Skemp, and the Quecn Victoria Museum, Launceston, Tasmania, are therefore to be congratulated on having made available some notable correspondence between R. C. Gunn-one of the great Tasmanian travellers and naturalists--R. W. Lawronce, Jorgen Jorgenson, Sir John Franklin and other botanists, and Sir William Jackson Hooker (one-time Regius professor of botany in the University of Glasgow and, later, director of the Royal Botanic Gardens, Kew), covering the poriod $1827-49$. Not everyone has a taste for these by-ways in the history of botany; but for those who wish to understand something of the pioneering work that made possible the compilation of an important Flora, and of the cumulative experience that afforded substantial and timely support to exponents of evolution at a critical time, a perusal of the present volume is likely to prove rewarding (Records of the Queen Vicloria Museum, Launceston (New Series). No. 14. Pp. $x i x+142$. Launceston, Tasmania: Queen Victoria Mnseum, 1961).

\section{Influence of Mental Tension on Diabetes Mellitus}

Heredry plays an essential part in the development of diabetes mellitus. States of mental tension, no matter how severe, cannot cause diabotes without an inheritod prodisposition to the disease. Mental stress can result in the appearance of overt diabetes among previously latent diabetics. It can also aggravate existing diabetes mellitus temporarily, and sometimes permanontly, especially in states of prolonged mental tension. This is so much the caso that, in mild cases previously controlled by diet alone, acidosis and evon pre-coma may result. In eight cases described by Dr. S. Sukiennik, Central Clinie, "Zamenhoff", Tel Aviv, diabotes appoared in four following severe mental tension (Dapim Refuim, 21, No. 2; Fehruary 1962). As the nervous tension decreased, the diabetes regressed to its latent stato or became mild and stabilized again. In the othor cascs, diabetes grew worso during montal stress, being tem- porary so long as the stress was temporary, but persisting while the stress continued. States of mental stress cause the over-secretion of steroids of the 11-oxy-steroid group. These substances lead to excessivo catabolism of proteins, and to the overproduction of glucose by means of gluconeogenesis in the liver. They also result in the decreased utilization of carbohydrates by the tissues, as well as changes in electrolyto balance. With storoid therapy, diabetes becomes manifest only among those with an inherited predisposition to the disease. Glucose tolerance tests with steroids show that even the tomporary increase of steroids can result in temporary changes in carbohydrate metabolism. This is seen also after excitement or following fits of anger in diabetes.

\section{The Royal Society and Nuffield Foundation Comm- onwealth Bursaries Scheme: Awards}

Awarns under the Royal Society and Nuffield Foundation Commonwealth Bursaries Scheme have been made as follows: Mr. J. K. Coulter, head of soil rescarch and survey section, regional rescarch centre, Univorsity College of the West Indies, to assist him to study the work on classification and fertility of tropical and sub-tropical soils being carried out by the Commonwealth Scientific and Industrial Research Organization in Australia, from December 1962 to February 1963; Dr. A. T. Cowie, Department of Physiology, National Institute for Rescarch in Dairying, Reading, to assist him to collaborate in research on the physiology of lactation at the Department of Animal Husbandry, University of Sydney, from April to June 1963; Dr. E. J. Denton, principal scientific officer, Marine Biological Association Laboratory, Plymouth, to enable him to visit Now Zealand and New Caledonia and related islands in order to study marine animals in environments different from those found in the English Channel and North Atlantic, for 3-4 months from mid-October 1962; Mr. J. R. Dunstone, lecturer in biochemistry, University of Queensland, to cnable him to pursue research into the physical aspects of biologically important mucopolysaccharides at the Lister Institute in 1963; Prof. J. F. Heard, professor of astronomy and director of the David Dunlap Observatory, University of Toronto, principally to assist him to study methods of stellar spectroscopy at other Commonwealth observatories, including Mount Stromlo, for about 2 months during 1963 ; Dr. J. I. Hubbard, Department of Physiology, Australian National University, Canberra, to enable him to study electron microscopy techniques at University College, London, from Septomber 1962 for 5-6 months; Mr. R. A. Jarvis, member of Soil Survey of England and Wales, to enable him to visit New Zealand at the end of 1962 for 3 months in order to make a critical comparison of red and yellow podzolic soils occurring there with the relevant English soils; Dr. T. F. Neales, senior lecturer in botany, University of Melbourne, to enable him to study techniques in the culture of excised plant roots at the University College of Swansea, in 1963 ; Prof. F. L. Yates, professor of physies, University College of Rhodesia and Nyasaland, to enable him to discuss problems of solid-state physics at Melbourne, from May until September 1962.

\section{Physiology and Psychology in Arid Lands}

A symposium on "Environmental Physiology and Psychology in Arid Conditions", organized by the United Nations Educational, Scientific and Cultural 